\title{
New Disease Reports \\ Atypical late blight symptoms following first recorded infections by Phytophthora infestans genotype EU_39_A1 in UK vine tomatoes
}

\author{
T.R. Pettitt ${ }^{1}$, G.J. Keane ${ }^{1}$, S.O.L. John ${ }^{1}$, D.E.L. Cooke ${ }^{2}$ and M. Žerjav ${ }^{3}$ \\ ${ }^{1}$ University of Worcester, Henwick Grove, Worcester, WR2 6AJ, UK; ${ }^{2}$ The James Hutton Institute, Invergowrie, Dundee DD2 \\ 5DA, UK; ${ }^{3}$ Agricultural Institute of Slovenia, Hacquetova ulica 17, 1000 Ljubljana, Slovenia
}

*E-mail: t.pettitt@worc.ac.uk

Received: 12 Feb 2019. Published: 10 May 2019. Keywords: lateral flow device, oomycete, Solanum lycopersicum

Early in 2018, Phytophthora late blight was recorded on young plants in at least five large UK vine-tomato nurseries. Infection (as high as 20\%) appeared limited to some batches of plants. Initially, affected plants showed some foliar and girdling stem lesions with a high rate of mortality. These were rogued and no secondary infection appeared to occur. Some infected plants $(<1 \%)$ survived. These had no foliar or fruit lesions. They were commercial grafts with two heads per rootstock generated by pinching the scion just above the cotyledons. Lesions started at the graft, generally affecting a single head per plant (Fig. 1), and extended up stems throughout the season at an average rate of 40-60 mm per week (Figs. 2-3). Tan-brown lesions, superficially resembling Botrytis stem rot, affected the outer stem layers (Fig. 4), not penetrating far into the vascular tissues and allowing shoot growth. Stem diameter was reduced compared to healthy vines, and fruit yield was reduced by about $25 \%$.

Isolations were confirmed as $P$. infestans by morphology and DNA sequencing using ITS6 and ITS4 primers (Cooke et al., 2000), and BLAST analysis (GenBank Accession No. MK507866). Isolates from three separate nurseries were fingerprinted using a 12-plex panel of simple sequence repeat markers (Li et al., 2013) and all were confirmed as genotype EU_39_A1. No other strains were identified throughout the epidemic. This genotype was first reported in Europe following monitoring in 2015 (Euroblight, 2015) when found mainly in garden tomatoes in $>24$ sites in Slovenia, on tomatoes in two gardens in Belgium, on two potato crops in Germany and a single potato crop in an allotment in south Wales. All subsequent UK records of EU_39 have been on potatoes: a single crop in Fife, Scotland in 2016 and once in a Bristol allotment, twice in eastern Scotland and once in Staffordshire in 2017. In the previous tomato cases in Belgium and Slovenia, EU_39 symptoms were more consistent with normal late blight, with high mortality and abundant sporulation on leaves and fruits (Fig. 5).

The presence of the pathogen was confirmed by sporulation from the cut ends of excised stems, divided into $50 \mathrm{~mm}$ segments and incubated at $100 \%$ relative humidity (RH) and $20^{\circ} \mathrm{C}$ for 36 hours. Cut stem segments were also incubated at a range of $\mathrm{RH}$ from $82-100 \%$, with sporulation seen at $\mathrm{RH}>95 \%$. Sporulation was determined by stereo microscopy and by swabbing small areas with $0.1 \%$ agar solution with cotton wool swabs for direct microscope observation and detection by immunodiagnostic assay lateral flow device (LFD) tests (Pettitt et al., 2018). Most sporulation was observed on cut stem ends, although increasing amounts were seen on stem surfaces at RH increasing from 95\%. LFD tests were more sensitive than microscope assessments. LFD results of swabs were compared with those from scrape samples (0.1-0.2 g surface tissue) from in situ stem lesions. Scrape samples mostly tested positive for Phytophthora and swab samples were mostly negative, confirming a general lack of sporulation throughout the largely dry tomato growing season in 2018. The potential for secondary disease spread as a consequence of sporulation was a major concern and LFD swab tests proved useful in assessing this and confirming the efficacy of sanitation at the end of the season.

\section{Acknowledgements}

The authors would like to acknowledge EuroBlight network (www.euroblight.net) for providing pathogen genotyping data and thank the UK Tomato Growers Association members for allowing free access to affected crops.

\section{References}

Cooke DEL, Drenth A, Duncan JM, Wagels G, Brasier CM, 2000. A molecular phylogeny of Phytophthora and related oomycetes. Fungal Genetics and Biology 30, 17-32. http://dx.doi.org/10.1006/fgbi.2000.1202

Euroblight, 2015. Genotype Map. https://agro.au.dk/forskning/international e-platforme/euroblight/pathogen-characteristics-and-hostresistance/genotype-map. Accessed 12 February 2019.

Li Y, Cooke DE, Jacobsen E, van der Lee T, 2013. Efficient multiplex simple sequence repeat genotyping of the oomycete plant pathogen Phytophthora infestans. Journal of Microbiological Methods 92, 316-322. http://dx.doi.org/10.1016/j.mimet.2012.11.021

Pettitt TR, Keane G, John S, Edwards E, Wakeham A, 2018. Development and Testing of Single and Multiplex Diagnostic Devices for Rapid and Precise Early Detection of Oomycete Root and Collar Rot Pathogens for Disease Avoidance, Management and Control. Final Report on AHDB Project CP 136. Stoneleigh, UK: Agriculture \& Horticulture Development Board, $58 \mathrm{pp}$.

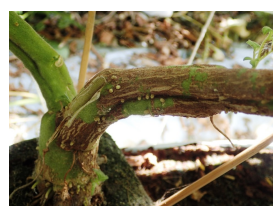

Figure 1

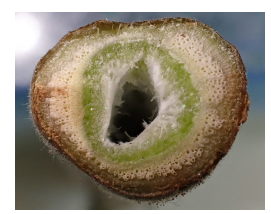

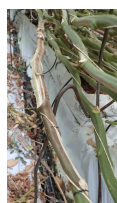

Figure 2

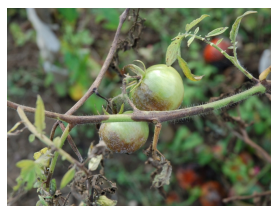

Figure 3

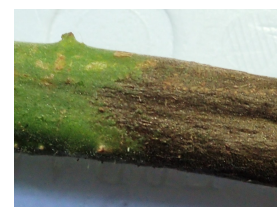

To cite this report: Pettitt TR, Keane GJ, John SOL, Cooke DEL, Žerjav M, 2019. Atypical late blight symptoms following first recorded infections by Phytophthora infestans genotype EU 39 A1 in UK vine tomatoes. New Disease Reports 39, 16. http://dx.doi.org/10.5197/j.2044-0588.2019.039.016 